\title{
MYTHOLOGICAL ARCHETYPES IN THE WORK OF VLADIMIR DIMITROV - THE MASTER
}

\author{
Elena Panayotova, PhD student \\ elena.panajotova@gmail.com
}

Sofia University "St. Kliment Ohridski", Department of Visual Arts, Sofia, Bulgaria

\begin{abstract}
In the work of the great Bulgarian artist Vladimir Dimitrov - The Master are applied mythological archetypes, studied theoretically today in the field of visual arts. The archetypes of the center, the radiant light, the connection of the figures with the background stand out. The master reflects the bride's fairy, the gentleness of the mother and the power of the rushed master - bathed in golden light. By painting, the Master worships the beauty and perfection of "eternal life."

These themes, visually developed by the Master, have been proposed for study and interpretation by students who, with enthusiasm, go in the footsteps of the great artist and show great results in their creative work..
\end{abstract}

Keywords: Vladimir Dimitrov - The Master; Mythological Archetypes; Eternal Life, Visual Arts

\section{МИТОАОГИЧНИ АРХЕТИПИ В ТВОРЧЕСТВОТО НА ВАААИМИР АИМИТРОВ - МАЙСТОРА}

\author{
Е^ена Панайотова, Аокторант
}

СУ "Св.Климент Охридски", катедра Визуални изкуствае Софияя, Бьлгария

Резюме: В творчеството на големия български художник В^аАимир Аимитров - Майстора са приложени митологични архетипи, изучавани Анес теоретично в областта на визуалните изкуства. Открояват се архетипите на центьра, на сияйната светлина, на връзката на фригурите с фонна. Майстора отразява фреерията на невестата, нежността на майката и силата на отрудения стопанин окъпани в златна светлина. Рисувайки, Майстора се прекланя преА красотата и съвьршенството на „вечния 
живот". Тези теми, визуално разработени от Майстора, са предложени за изучаване и интерпретиране от ученици, които с възторг и ентусиазъм тръгват по стьпките на големия художник и показват високи резултати в своята творческа работа.

КАючови Ауми: ВАаАимир Аимитров - Майстора, митологични архетипи, вечен живот, визуални изкуства

Владимир Аимитров - Майстора е „наречен „Майстора“ още като студент в Аьржавното рисувателно училище заради неповторимия си талант" (Karanfilova, 2012: р. 4). В зрялото си творчество той рисува „вечния живот"1 - моми, Аеца, майки в обляни от сльнце овощни и цветни градини, жетвари среА з^атните житни по^я.

Анес изучаваме т. нар. митологични архетипи на визуално изразяване. А Майстора интуитивно е знаел как да ги впише в своите картини - така, че момата на фона на плодове и цветя $\Delta а$ бъле така омайващо чиста, сияйна, жизнена и в същото време изльчваща онзи опияняващ потенциал на бълещо майчинство, благодарение на който Майстора казва: „Каквото и да третирам, аз рисувам вечния живот“. Той изгражАа мощна и въздействаща градация - цветето, плоАът, Аетето...и после момата и майката, нежно прегьрнала своето детенце. Как Майстора постига тази сила във визуалния израз, внушаваща вечната връзка межлу природата и майката, межлу земята-майка и нейните чеда, и земните майки? „Аз свьрзвам, при всяка идея, човека с вселената, която трепти от радост и взема участие във всичко, което той прави. Каквато и илея да третирам, третирам вечния живот"- казва Майстора².

Мирча Елиале казва: ... земята Майка... тя поражда всички нови форми... Земята е жива най-вече защото е плодородна... Човекът може

\footnotetext{
1 Текстове, придружаващи изложба на платна на Владимир Аимитров Майстора /юни-август 2012/ в Националната художествена галерия.

2 Пак тези текстове
} 
да бъле живо същество само защото излиза от земята, ражла се от Земята-Майка" (Eliade, 2012: р. 274). Именно тази животворяща ЗемяМайка, която рисува Майстора. Той рисува сльнчев, Ааващ живот фрон зал момичетата и децата, сякаш за да покаже, че всичко живо на земята е свързано, както и да засили усещането за бъдещия живот,

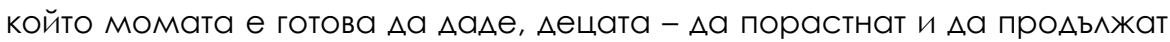
също свещенната, вечната жизнена пьтека. Пьтеката на ^юбящи майки и работни жетвари, на сплотени семейства. Следователно, наблюдаваме характерен архетип, построен на принципа на схолство, силна връзка и взаимно усилване на въздействието межАу централната фоигура и животворящия фоон - основа на живота. Сякаш Майстора е извел на преден план най-силния от всички елементи в момента на рисуването. Защото силата на природата, на Земята-Майка е със същата посока на развитие, на стремеж, на неутолима жажла за реализиране. Тя полкрепя и емоционално зарежла с още повече сльнчев потенциал детето, момата, невестата, жетваря... И отнова Мирче Елиале сполеля: ...межлу Земята и поролените от нея орорми съществува магическа врьзка... Всички тези фрорми образуват в съвкупност еАинна система. Невидимите Нишки, свързващи растителността, животните и хората от Аалена местност с почвата, която ги е породила, отгледала и хранила, са изтькани от живот, пулсиращ в самата Майка, и в нейното съзнание. Връзката между телуричното ... и растителното ... е о обусловена от живота, който навсякъле е елин и същ." (Eliade, 2012: р. 275). Именно тази връзка е прозрял Майстора и я е рисувал неуморно. 


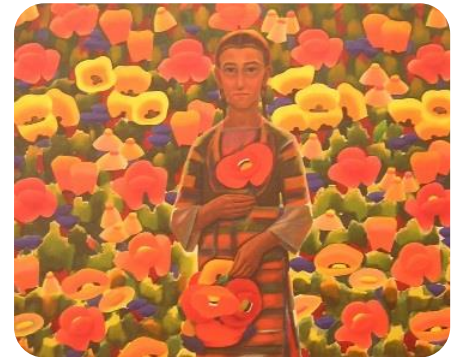

Фиг.1. Момиче с макове, 1930,

ВА. Аимитров-Майстора, НХГ

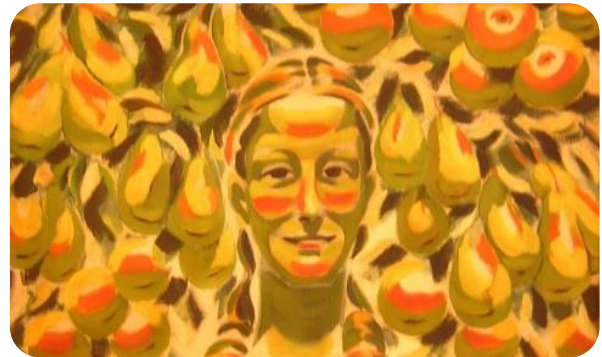

фиг.2. Момиче на фон от круши и ябълки, 1935, ВА. Аимитров-Майстора, ХГ Стара 3aropa

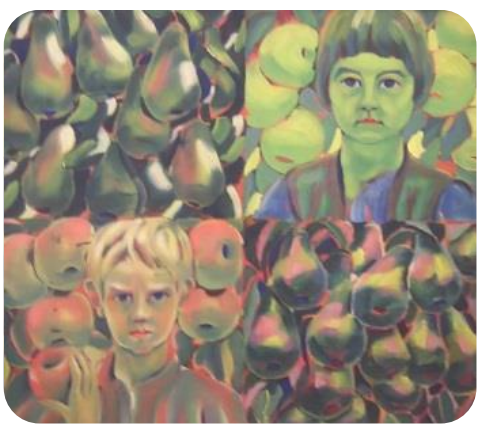

Фиг. 3. Аеца и плоАове, 1935, ВА.Аимитров-Майстора, НХГ

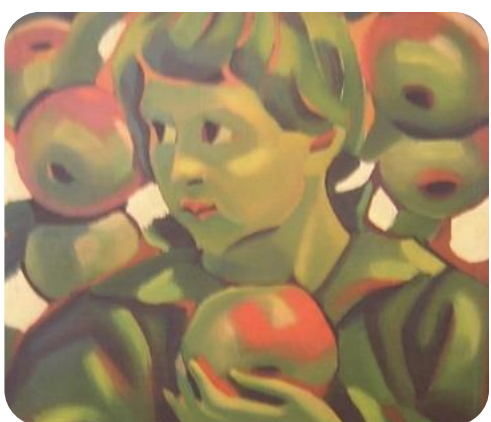

Фиг. 4. Момче с ябълки, 1930, ВА.Аимитров-Майстора, НХГ

Мирча Елиале говори за „Земята-Майка и нейния човешки представител - жената...", която „имала възможност Аа обърне внимание на естествените процеси на осеменяване и поникване и да се опита да ги възпроизведе изкуствено. Освен това ... жената прилобила особен престиж, тъй като се смятало, че е способна $А а$ влияе върху плодородието и разпределянето на произвежАащите сили" (Eliade, 2012: рр. 277-278). А Майстора рисува с преклонение и възторг тази вьлшебница, която дарява живот. „Мистичното еАинство, тайнствената връзка между плодородието на земята и съзидателната си^а на жената е елна от фрундаменталните структури, Аьлбинна 
интуиция за онова, което можем да наречем „земеделско съзнание“"“ (Eliade, 2012: p. 353).

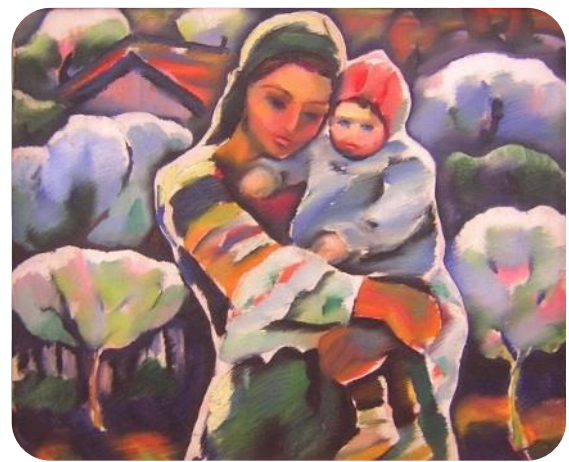

Фиг.5. Майка поА цъфннало Аърво, 1935, ВлаАимир Аимитров-Майстора, НХГ

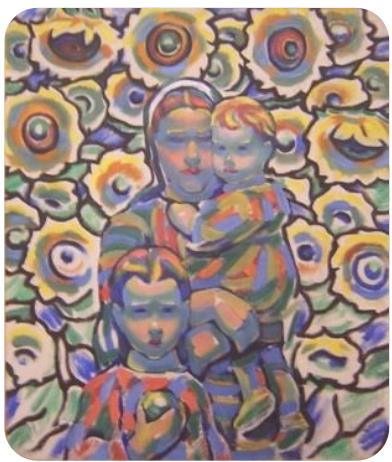

фиг.6. Майка с Аеца, 1935, ВАаАимир Аимитров-Майстора, $\mathrm{HX \Gamma}$

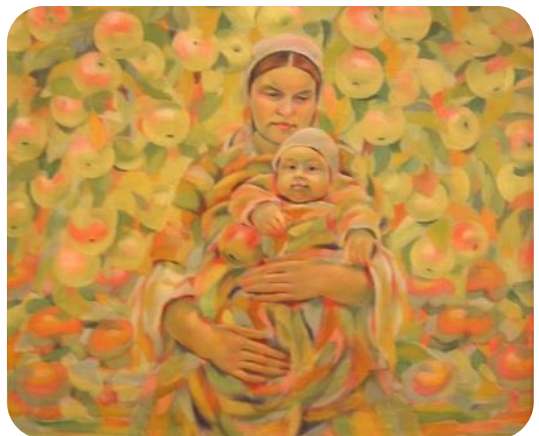

Фиг. 7. Майка с Аете, 1935, ВАаАимир Аимитров-Майстора, ХГ КърАжами

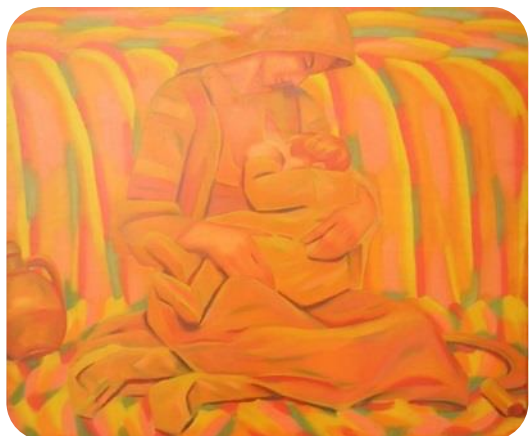

Фиг. 8. Жътварка (На нивата), 1935, ВлаАимир Аимитров-Майстора, НХГ

"Майката прави всичко възможно за децата си" (Kaftandziev, 2015: р. 40). И как $\Delta а$ не бълем запленени от онази безкрайна проникновина нежност, с която майките на Майстора са прегърнали своите рожби? Вечна, безусловна обич и нежност, която пребьлва през 
годините и която е заложена изначално у жената-майка, от Бога Аалена. И тази Божествена обич струи от картините на Майстора.

Майстора не забравя и Жетваря - окъпан в з^ато, облян от сльнчеви ^ьчи, сля^ себе си с житните снопове в името на живота, е Символ на „героят, който трябва $А$ изпьлни трудна залача" (Kaftandziev, 2007: р. 84) - да се грижи за прекрасните деца, майките, невестите и да направи така, че да пребьле красотата, мьдростта и силата на рода.

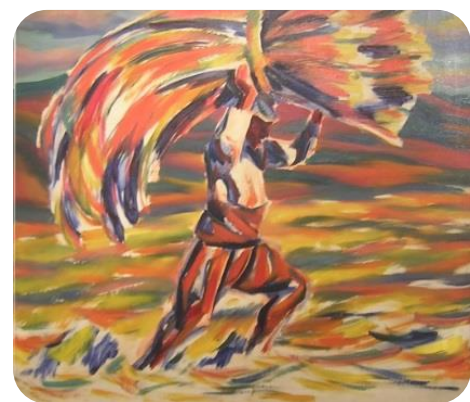

Фиг.9. Жътвар, 1935-1938,ВлаАимир Аимитров-Майстора, НХГ

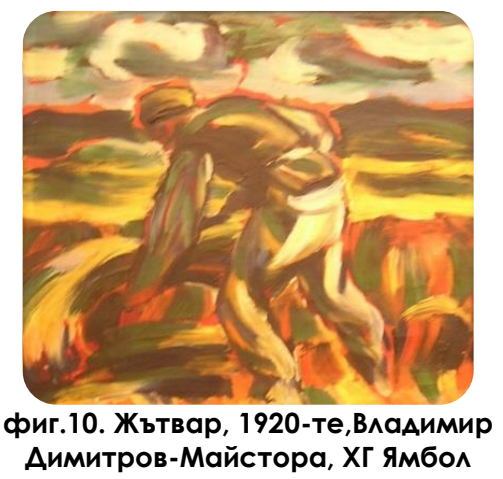

Аимитров-Майстора, ХГ ямбол

"Свързано с живота, имащо за пряка цел гигантското нарастване на скритите в семената, в браздата, в АъжАа, в растителните духове жизнени сили, земеделието е най-вече ритуал. ... Орачът прониква в зона, във висша степен наситена със свещено сьльржание." (Eliade, 2012: р. 351). СпореА Елиале реколтата е "свещена сила", олицетворявана с "Майката на живота", "Великата майка", "Майката на класовете" (Eliade, 2012: р. 358). Именно за тази Майка се грижи и жетварят на Майстора, с благоговение понесъ^ житните снопове.

Майстора рисува живота с неговите Аелници и празници. А еАин от най-Аичните празници е сватбата. И художникът, зап^енен от

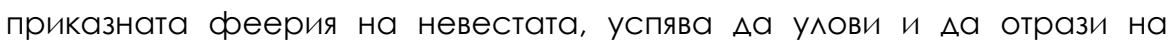


платното сиянието, което тя изльчва и светлината, бликаща и огряваща благодатно наоколо - на сватбеното хоро, в момента на ръкоцелуването на ръката на свекъра. Извайва образа на булката още по-чист, озарен, великолепен! Усещането за непорочност великият художник засилва с нежни розово-бели цветове нал главата на невестата ... и сякаш Аолавяме уханието им от платното.

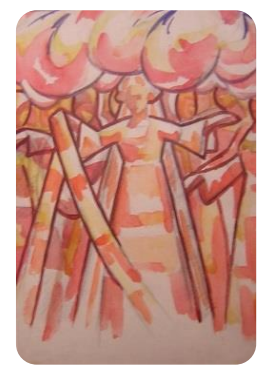

Фиг 11. Невеста води хоро, 1930-1935, ВАаАимирАимитровМайстора, ХГ Кюстенаии

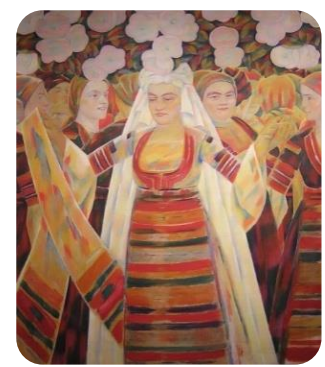

фиг.12. Сватбено хоро 1930-1935, ВАаАимир Аимитров-Майстора, $\mathrm{HX \Gamma}$

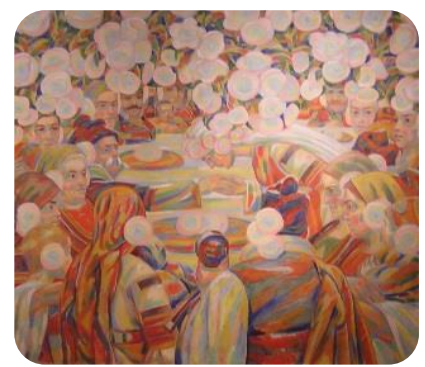

фиг.13. Сватба. Ръкоцелуване, 1935, ВАаАимир АимитровМайстора, НХГ

В картините на Майстора героите са обгьрнати от розово-з^атна светлина, зарежАаща с благолат и мъдрост. Профо КафртанАжиев прави разбор на значението на цветовете: „...белият цвят изразява светостта и божествената енергия, златният - вечността, величието, Съвьршенството,... изразява Аьлбинни Ауховни Същности, розовият Аетството" (Kaftandziev, 2015: рр. 64-65). Съчетанието на цветовете около образите на Майстора сьздава сияние, носещо ореола на мьдростта и Ауховността на българското. „Белият цвят... изразява трансцеАентността - елновременно и светлина и цвят" (Kaftandziev, 2015: р. 65). Белият, с нежни розови оттенъци ябълков цвят в композициите с невестиното хоро, с рькоцелуването - светлина в душата и благодат в живота. 
Основния, значимия образ Майстора поставя в центьра на композицията. Центьрьт - както „центьрьт на света“ (Eliade, 2012: р. 253), „както всички осветени храмове, Аворци и центрове“, където се съединяват небето и земята и представлява „свързващо звено между различните космически равнища" (Eliade, 2012: p. 254). E^иале пише, че "п^одородието е най-вече свойство на центьра и нерядко неговите символи имат сексуален характер" (Eliade, 2012: р. 255).

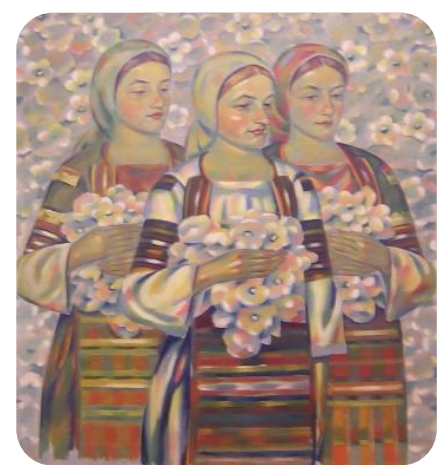

Фиг.14. Три сестри, 1929, ВлаАимирАимитров-Майстора, НХГ

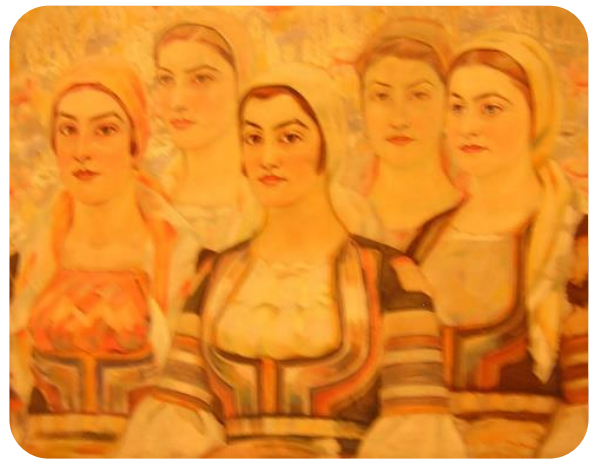

фиг.15. Пет Аевойки, 1929, ВАаАимир Аимитров-Майстора, НХГ

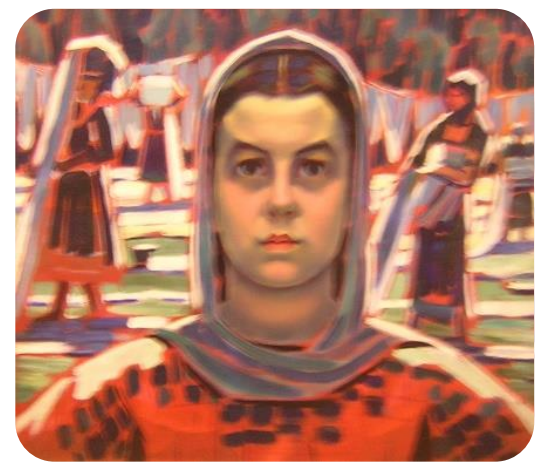

Фиг. 16. Белят платна, 1930, ВлаАимир АимитровМайстора, НXГ

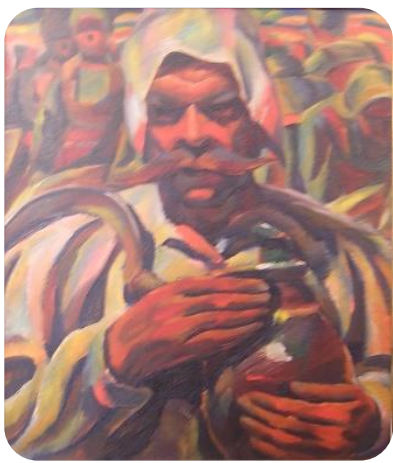

Фиг. 17. Жътвар, 1938, ВлаАимир АимитровМайстора, HXг 
Митологичният архетип на центьра - "централната позиция на Христос" (Аали) (Kaftandziev, 2015: р. 66), Аеориниран и от Мирча Елиале в Митьт за вечното завръщане като: „Свещената Планина, къАето се срещат Небето и Земята, ... всеки храм или Аворец..., ос на света...Сътворението на човека е станало в някакво централно местоположение ... на пьпа на земята" (Eliade, 1994: р. 20). "Центьрьт е еАно от най-важните понятия по отношение на знаковите аспекти на пространството... В центьра живее ГоспоА...затова центьрьт е голям, осветен, симетричен и чист" (Kaftandziev, 2015: р. 112). В центьра на картините на Майстора е Молоната, невестата, момата - като Божествена еманация на земята. А относно симетрията - в картините на Майстора можем да говорим за баланс. Фигурите отляво и отАясно балансират и засилват възАействието на централната фригура боготворена, нарисувана с ^юбов.

И нравствената чистота на българката е изразена убелително в светлина и цвят в картините на Майстора. А архетипьт чистота ясно изразява илеята за доброто (Kaftandziev, 2015: р. 273). В случая говорим за чистота отвьА земните представи, чистота на Аушевността, мисьлта, емоцията. И ги откриваме в най-висша степен в картините на Майстора, изразени визуално така силно, така завлаляващо - с Ауми е трудно да се опише усещането, което художникът проектира у всеки, Аокосна^ се до неговото творчество (Kaftandziev, 2013).

Щастието изразяваме с ярки цветове - като децата. А Аушата на Майстора винаги помни детската възторженост, прекланяйки се преА живота, го рисува в искрящи, ярки, щастливи тонове. 


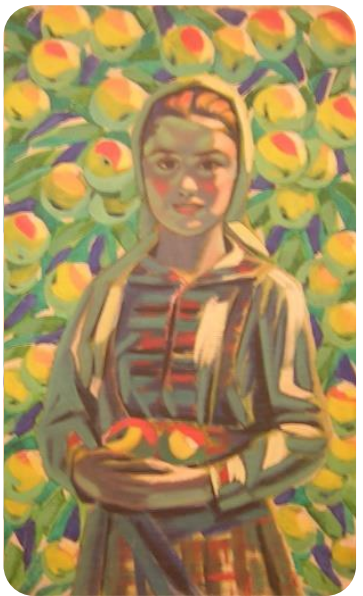

Фиг.18. Аевойка, 1949, Х ВлаАимир АимитровМайстора, ХГ Бургас

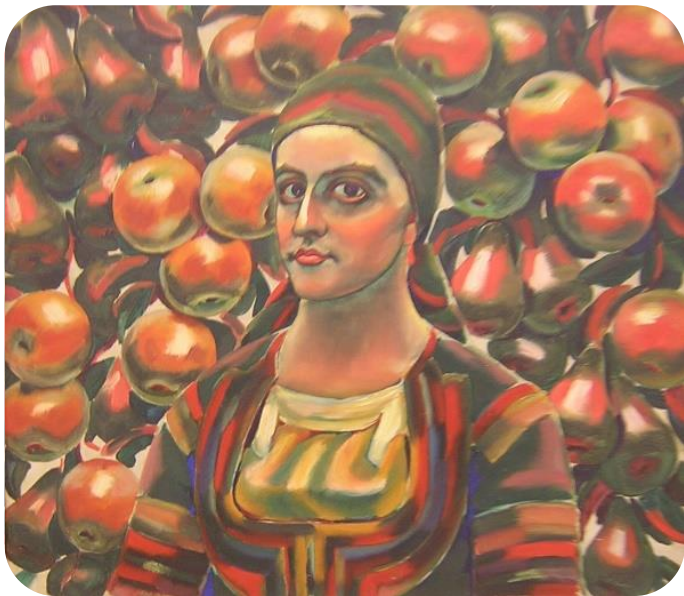

фиг.19. ТоАора, 1935, ВАаАимир АимитровМайстора, ХГ КюстенАиА

Безвремие е другото име на творчеството на Влалимир Аимитров - Майстора, защото неговите творби изразяват безсилието на времето в името на вечните илеали, които той щеАро ни е завещал в образи. В митературата безвремието е дефинирано чрез категориите нирвана и удоволствие (Kaftandziev, 2016: р. 280), които са свойствени стремежи на човешката психика. Съзерцаването на творбите на Майстора е състояние, много близко до тези категории, изведени в техните най-позитивни и най-висши аспекти - Аоколкото земният живот прелполага в неговата вечност и приемственост.

За силата на жената профр. Кафртанджиев дава опрелелението: „Изк^ючителен тип мощ" (Kaftandziev, 2015: р. 39). Той напомня, че „жената никога не е била доминирана, а винаги е била Аоминираща" (Baudrillard, 1990: р. 15). "Женската харизма ...изк^ючителната женска красота" (Kaftandziev, 2015: р. 40) и нейното огромно значение за човешките отношения и хола на живота - фоакти, в силата на които Майстора ни убежлава визуално. 
Нещо повече, художникът ни внушава притежаването на сврьхестествена си^а на българската жена. Сякаш за неговите картини и за българската мома и невеста Вебер отбелязва „харизма сврьхестествена, сврьхчовешка или поне специфрично извьнвсекилневна, наларена с недостьпни за всеки Аруг сили и качества,...богоизпратена..." (Veber, 1992: р. 65).

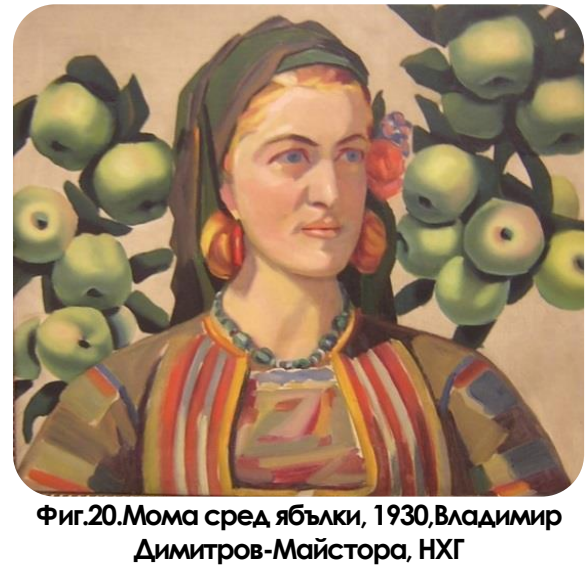

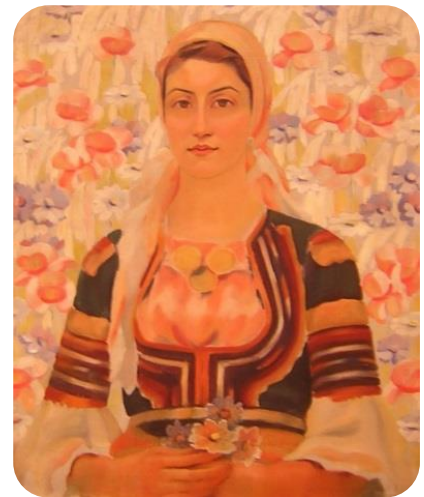

фиг.21. Мома от Калотинци, 19291930, ВАаАимир АимитровМайстора, НХГ

Рисувайки, Майстора се прекланя преА красотата и изяществото на живота и с радост и възхищение неуморно го отразява на платното. Архетипите на центьра, сияйната топ^а светлина и силата на женското нача^о са приложени интуитивно от Майстора в неговото творчество. И вероятно Аопринасят за силата на въздействието на Майсторовите образи. Аолавяме голямата любов, с която големият български хуАОЖник гИ СъзАава.

Тези живописни образи днес представляват значима част от националната ни култура и от нашето нематериално културно HaC^еАствO. 
Темата за изградените от Майстора образи от гледна точка на митологичните архетипи беше предложена на учениците от осми к^ас. СлеА полробно запознаване на учениците с творчеството на Майстора, разясняване и Аискутиране на основни положения, отнасящи се Ао изведени митологични архетипи, учениците с откриха и посочиха изградените от Майстора архетипи. Анализираха голям брой композиции, съзАадени от ВАадимир Аимитров - Майстора. И ... заредени с възторг и ентусиазьм, опитаха Аа съзАадат свои композиции, сиАно повлияни от големия наш хуАОЖник:

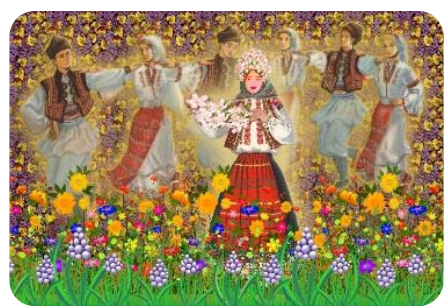

Фиг.22.Ученическа композиция

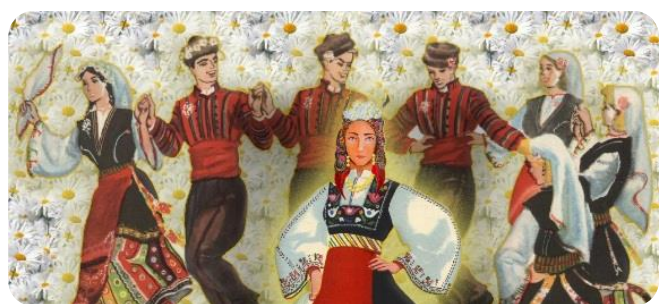

фиг.23. Ученическа композиция

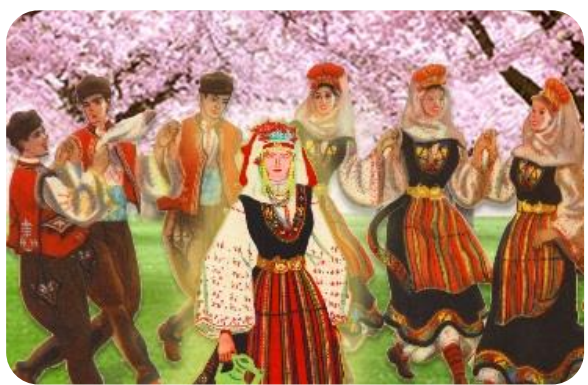

Фиг. 24.Ученическа композиция

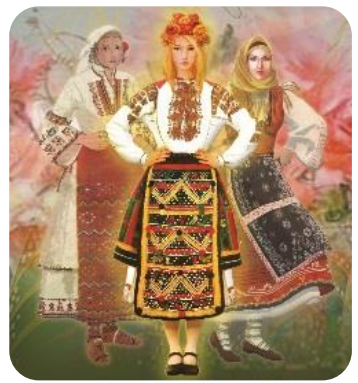

Фиг. 25.Ученическа композиция 


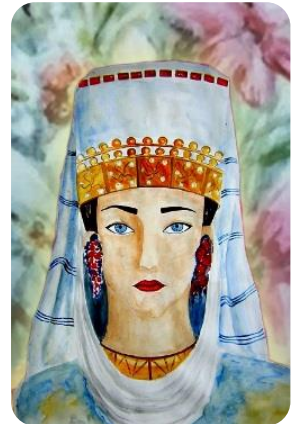

Фиг. 26.Ученическа композиция

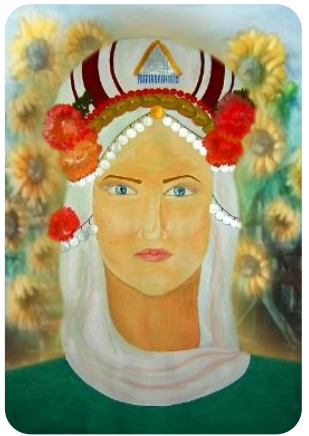

Фиг. 27.Ученическа композищия

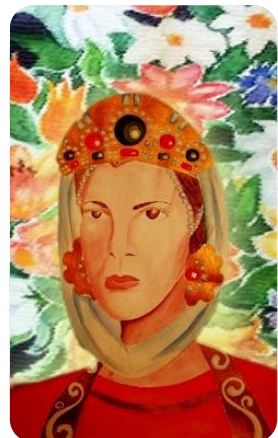

Фиг. 28.Ученическа композиция

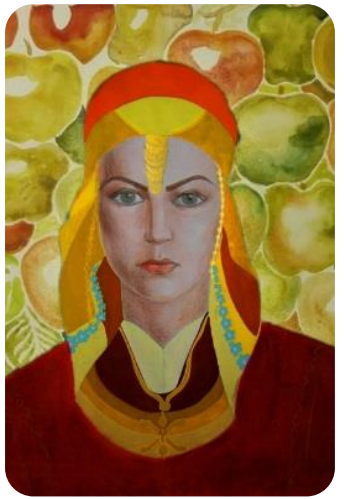

Фиг. 29.Ученическа композиция

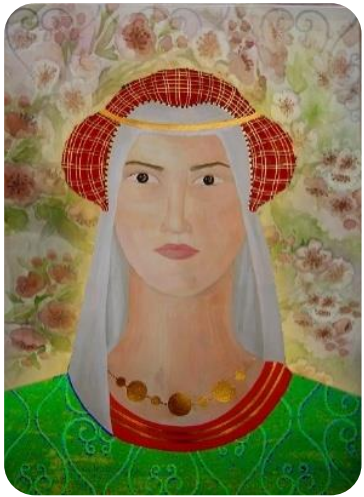

Фиг. 30.Ученическа композиция

Учениците се постараха $\Delta$ а приложат знанията си за митологичните архетипи. Работиха в часове по изобразително изкуство и приложен софртуер. Комбинираха нови знания относно теория на визуалната комуникация с умения по изобразително изкуство и компютьрна графрика. Почувстваха се горди наслеАници на обичания от всички нас ВАаАимир Аимитров - Майстора. 


\section{^итература / References}

Baudrillard, J. (1990). Seduction, New World Perspectivesq 1990

Eliade, M. (1994). Mitat za vechnoto zavrashtane (in Bulgarian), Publisher: "Publisher house Hristo Botev", Sofia, Bulgaria, 1994 // [E^иале, М. Митьт за вечното завръщане, Иза. Къща „Христо Ботев“, Софиия, 1994]

Eliade, M. (2012). Traktat po istoria na reliigiite (in Bulgarian), Publisher: "Iztok Zapad", Sofia, Bulgaria, 2012 // [Елиале, М. Трактат по история на религиите, ИзА. Изток Запал, Софрия, 2012]

Kaftandziev, Hr. (2007). Geroi i krasavitci (in Bulgarian), Publisher: Siela, Sofia, Bulgaria, 2007 // [Кафтанджиев, Хр. Герои и красавици, Сиела, София, 2007]

Kaftandziev, Hr. (2013). Harmonia $\vee$ reklamnata komunikacia (in Bulgarian), Publisher: SU, Sofia, Bulgaria, 2013 // [Кафртанджиев, Хр. Хармония в рекламната комуникация, СУ, 2013]

Kaftandziev, Hr. (2016). Integrirani marketingovi komunikacii (in Bulgarian), Publisher: SU, Sofia, Bulgaria, 2016 // [КафртанАжиев, Хр. Интегрирани маркетингови комуникации, СУ, софрия, 2016]

Kaftandziev, Hr. (2015). Mitologichnite arhetipi $\vee$ komunikaciite (in Bulgarian), Publisher: Su, Sofia, Bulgaria, 2015 // [Кафртанджиев, Хр. Митологичните архетипи в комуникациите, СУ, София, 2015]

Karanfilova, S. (2012). Vladimir DImitrov - Maystora (in Bulgarian), Publisher: NHG, Sofia, Bulgaria, 2012 // [Каранфилова, С. Владимир Аимитров-Майстора, НХГ, Соория, 2012]

Veber, M. (1992). Sotciologiata na gospodstvoto. Sociologia na religiata (in Bulgarian), Publisher: SU, Sofia, Bulgaria, 1992 // [Вебер, М. Социология на госполството. Социология на религията, СУ, Софрия, 1992] 
КУАТУРНО-ИСТОРИЧЕСКО НАСАЕАСТВО: ОПАЗВАНЕ, ПРЕАСТАВЯНЕ, АИГИТААИЗАЦИЯ

\section{CULTURAL AND HISTORICAL HERITAGE: PRESERVATION, PRESENTATION, DIGITALIZATION}

Научна пореАица: брой 1(6), гоАина V (2019)

Science series: volume 1(6), year V (2019)

\section{ISSN: 2367-8038}

\section{Релактори \\ Петко Ст. Петков \\ Галина БогАанова \\ Институт по математика и информатика БАН, Бъмгария}

Материалите в сборника са обект на авторско право. Разрешава се безвъзмезАното ползване на техни електронни/ хартиени копия само

за лична употреба или с цел обучение, при писмено указание за Аипса на търговски намерения и пь^но цитиране на текста от тази

страница.

За копиране под Аруга орорма, препубликуване или публикуване на сървъри се изисква писмено разрешение и/и^и зап^ащане.

() Авторски колектив, 2019

Технически реАактори: Николай Ноев, гА. ас. А-р Калина Сотирова-Вълкова, ас. А-р

\author{
Editors \\ Petko St. Petkov \\ Galina Bogdanova \\ Institute of Mathematics and \\ Informatics \\ BAS, Bulgaria
}

This work is subject to copyright. Open and free use of digital/ hard copies of publications is granted only for personal or educational use, while there are written statement for not-commercial intention and full citation of the text of the current page.

For any other reproducing types, re-publishing, photocopying, recording, orany other storage retrieval system/server is required written permission and/or fee.

(C) Authors` Group, 2019

Technical editors:

Nikolay Noev, Assist. Prof. PhD Kalina Sotirova-Valkova, Assist. Prof. $\mathrm{PhD}$ 